\title{
Encontrar-te:
}

\section{trajetos poéticos e invenção de lugares}

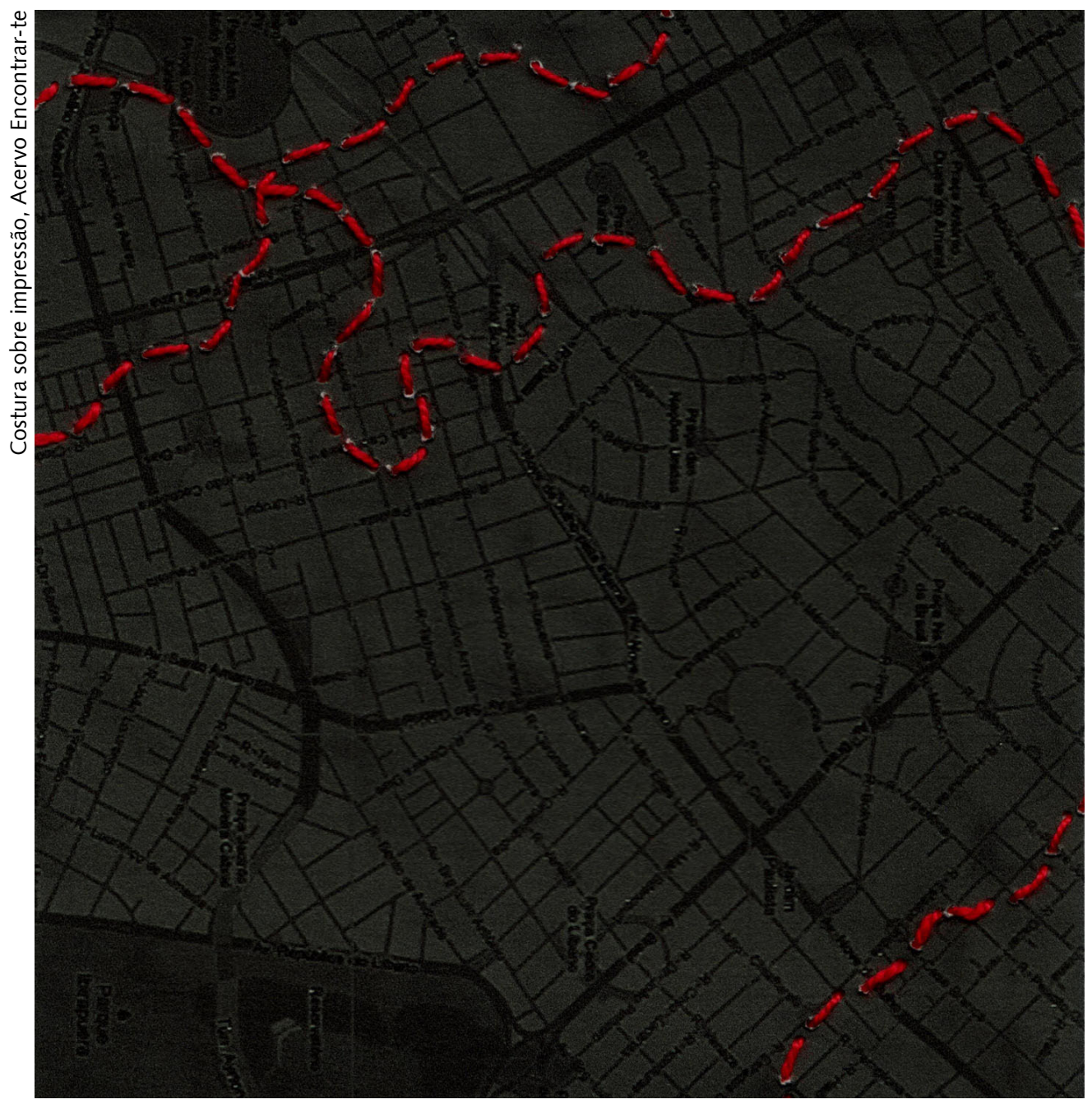

Gisele Dozono Asanuma(a) Isabela Umbuzeiro Valent ${ }^{(b)}$ Mariana Louver Mendes ${ }^{(c)}$

Existem vários modos de circular pela cidade.

Como habitamos o nosso cotidiano?

Como podemos criar ( $\mathrm{n}$ )o espaço que habitamos?

Encontrar outros e juntos encontrarmos a cidade.

Descobrir novas formas de estar nos espaços sociais.

(a, b) Programa de

Pós-Graduação Internunidades em Estética e História da Arte, Universidade de São Paulo (USP).

Rua da Praça do Relógio, 160-A, Cidade Universitária. 05508050. São Paulo, SP, Brasil. gisele.asanuma@usp.br; isabelavalent@usp.br

(c) Terapeuta ocupacional. São Paulo, SP, Brasil. ma.louver@gmail.com 


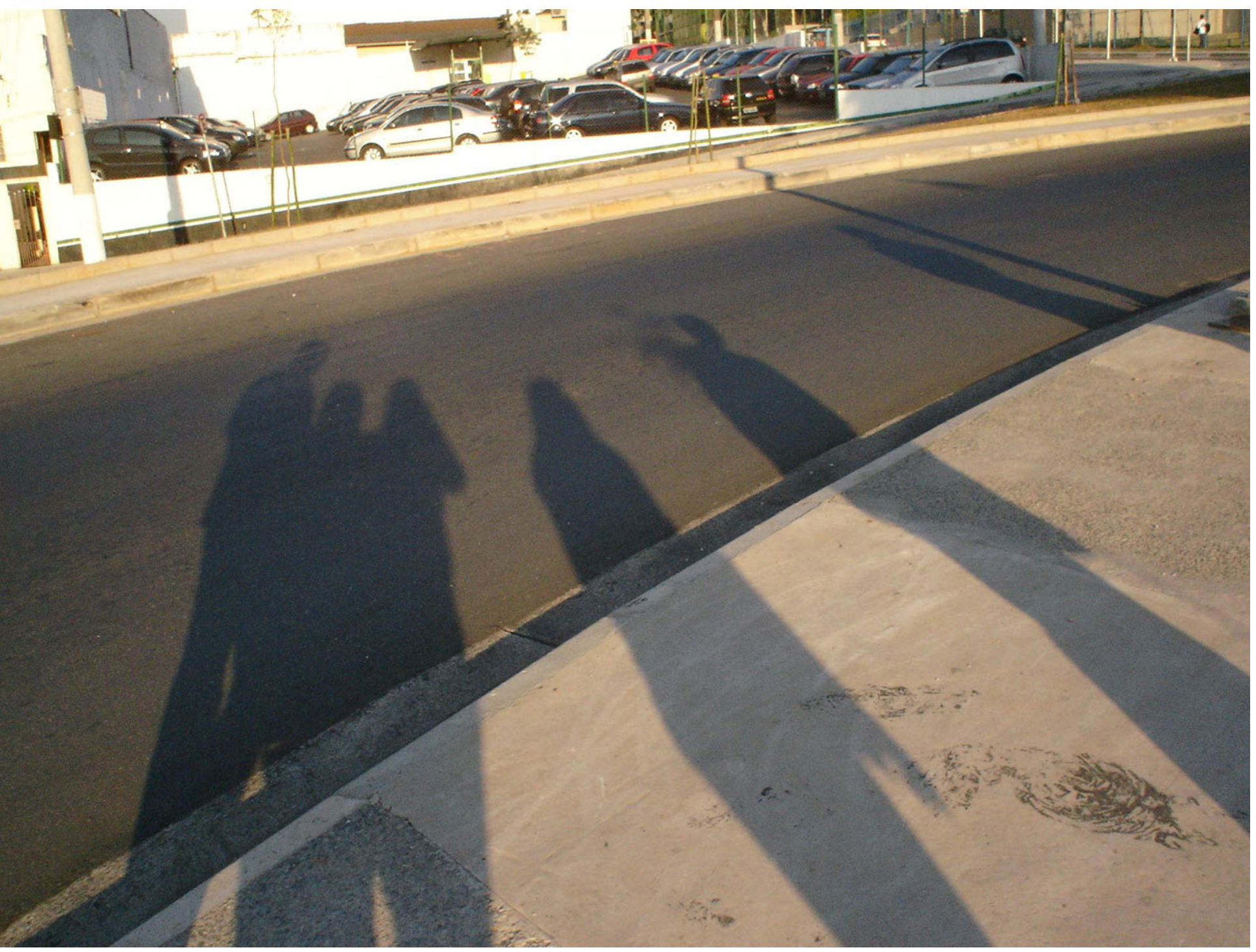

Registro fotográfico de ação coletiva, Acervo Encontrar-te

Em 2005, a partir de inquietações provocadas no encontro de duas estudantes de terapia ocupacional com seus primeiros pacientes, surge o Encontrar-te, um projeto que teve como mote a circulação na cidade de São Paulo,Brasil, por lugares $\mathrm{da}$ arte e da cultura e as diversas formas de conviver na cidade. Inquietava que a circulação dessas pessoas parecia se restringir aos seus espaços de tratamento.

Em um primeiro momento a proposta foi desenvolvida com o apoio do Programa Composições Artísticas e Terapia Ocupacional da Universidade de São Paulo (PACTO-USP) e posteriormente o grupo seguiu de forma autônoma até o início de 2014, contando com a participação de diversos profissionais.

A proposta constituía-se de um grupo aberto à participação de qualquer pessoa, independente de condições sociais e/ou de saúde, no qual se desejava a diferença e o olhar para as singularidades. Investia-se em uma prática conectada com a invenção de formas de vida, de estar com o outro e de habitar a cidade, compondo dispositivos que favorecessem expressões poéticas, criativas e sensíveis e que operassem a inauguração de gestos singulares. 
Intercalar encontros no consultório-ateliê com saídas pela cidade era o pulso que mantinha o grupo vivo. Nos dez anos de existência, muitas experimentações ocorreram: fotografias, performances, xilogravuras, vídeos, trabalhos corporais, exercícios de escrita, desenhos, intervenções urbanas, colagens, mapas, serigrafias, pinturas, mosaicos, comidas e viagens.

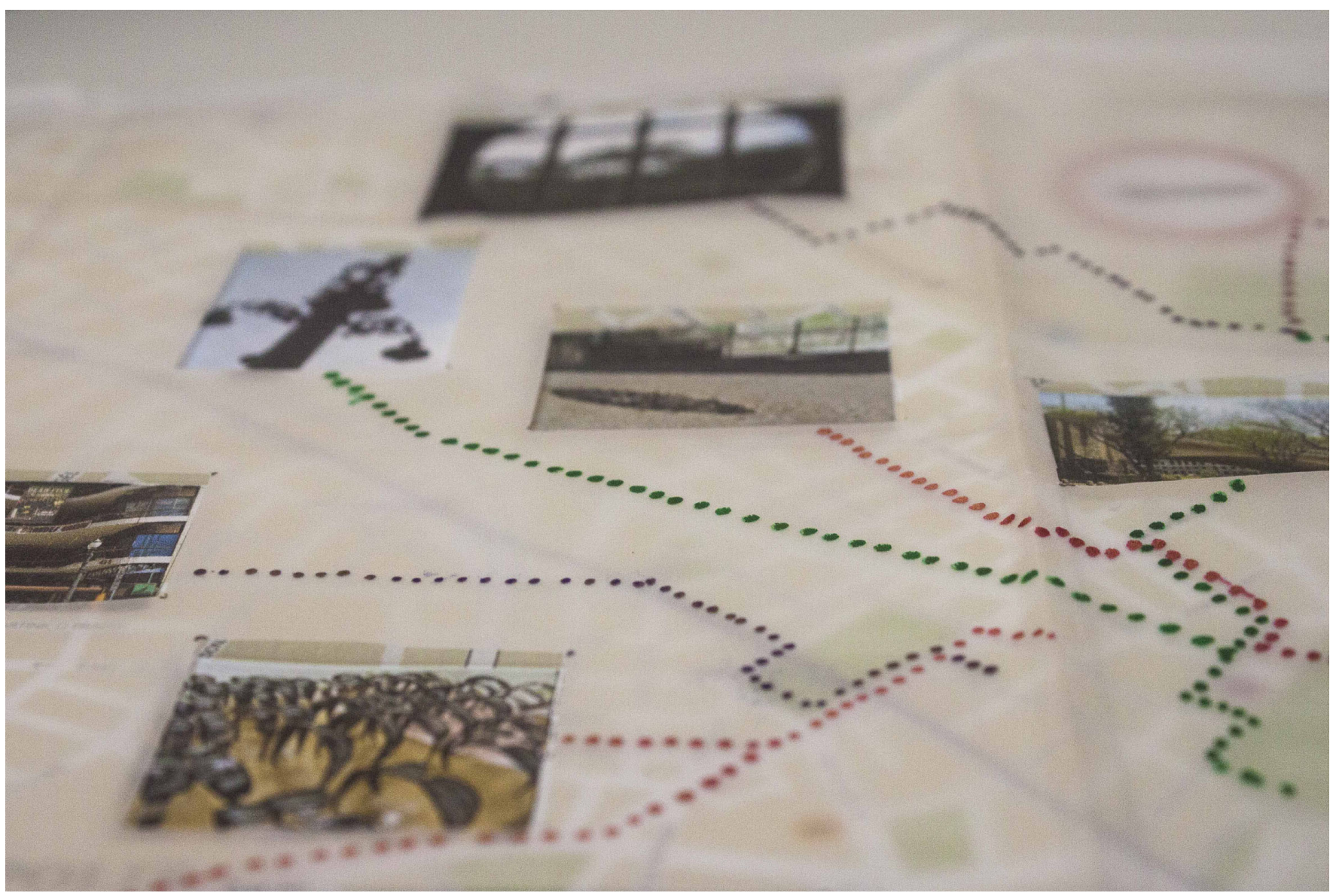

Registro fotográfico do livro objeto Cartogafias Encontrarte, de Gisele Asanuma, Acervo Encontrar-te

"O que é importante não são nunca as filiações, mas as alianças e as ligas; não são os hereditários, os descendentes, mas os contágios, as epidemias, o vento. As bruxas bem o sabem". ${ }^{1}$ (p. 83) 


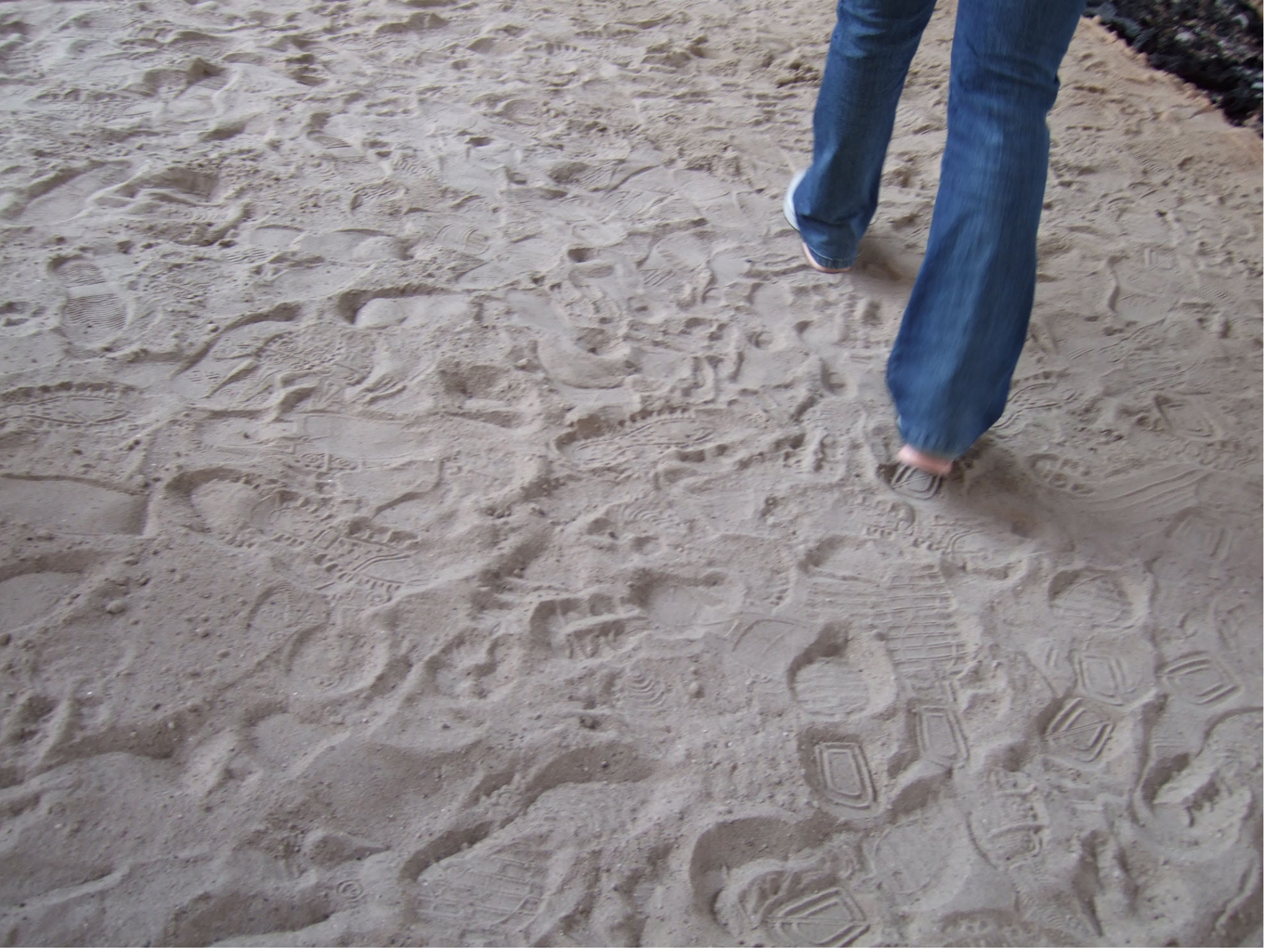

Registro fotográfico de ação coletiva, Acervo Encontrar-te

Mas um meio é feito de qualidades, substâncias, potências e acontecimentos: por exemplo a rua e suas matérias, como os paralelepípedos, seus barulhos, como o grito dos mercadores, seus animais, como os cavalos atrelados, seus dramas [...]. O trajeto se confunde não só com a subjetividade dos que percorrem um meio mas com a subjetividade do próprio meio, uma vez que este se reflete naquele que o percorre. O mapa exprime a identidade entre o percurso e o percorrido. Confunde-se com seu objeto quando o próprio objeto é movimento. $^{2}$ (p. 73) 


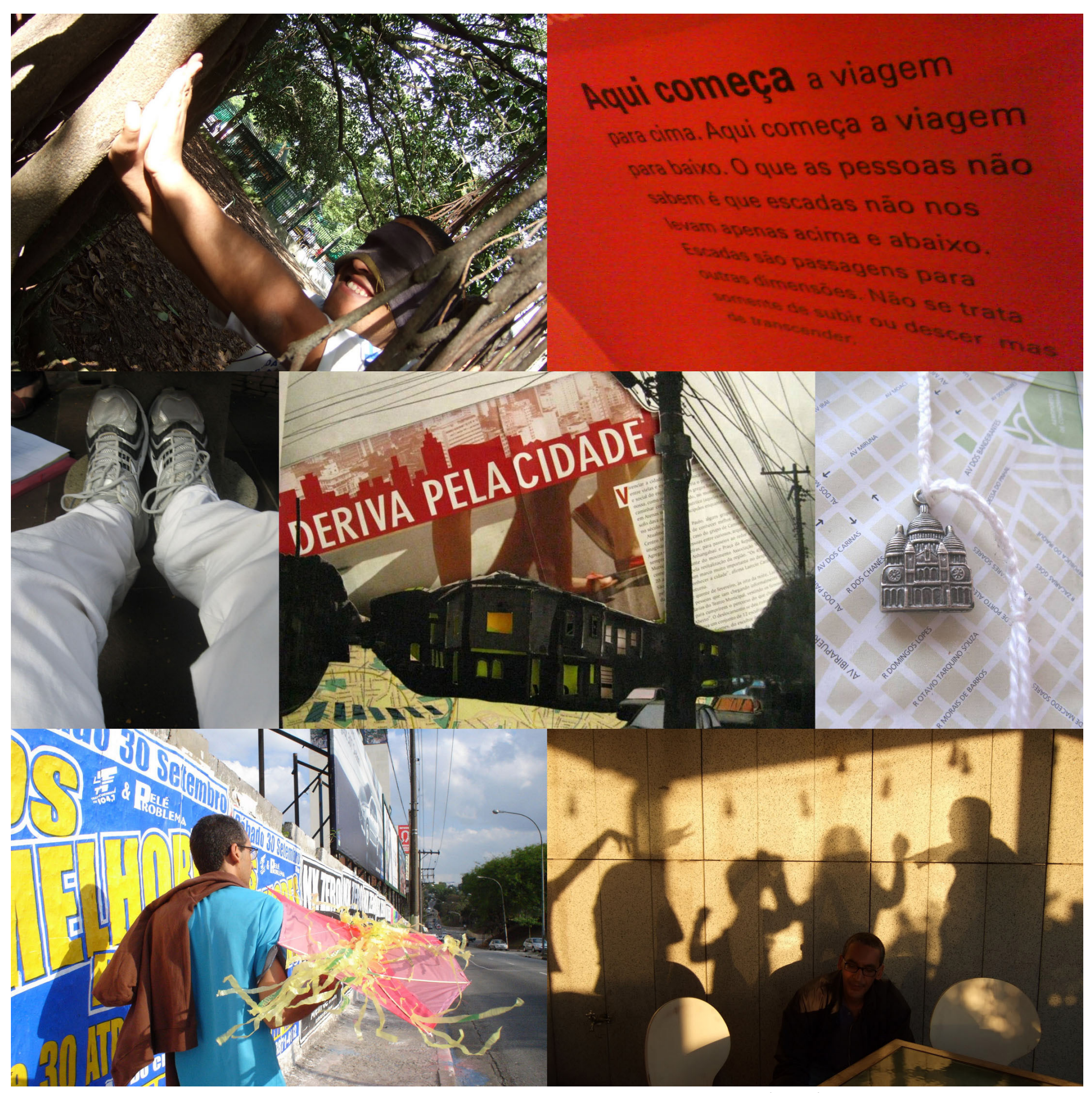

Registro fotográfico de ação coletiva, Acervo Encontrar-te

As alegrias proporcionadas por aquelas tardes eram inúmeras. Naqueles dias víamos a cidade de outros modos, circulávamos por novas ruas, com outras velocidades. Uma estranha alegria, que emocionava. Talvez pela experimentação que podíamos viver juntos. Pela intensa sensação de liberdade e desobrigação. ${ }^{3}$ (p. 91) 
Nenhum compromisso formal com os moldes esperados em um encontro circunscrito a enquadres clínicos. O que mais importava era garantir a presença e o encontro. Nem a clínica, a cura, a produção de obras, a arte, a cultura e nem mesmo o eu estavam obrigados a nada. Nenhuma demanda a responder, ninguém a incluir, nada prescrito a fazer. A mobilidade, a ausência de formatações era o que interessava.

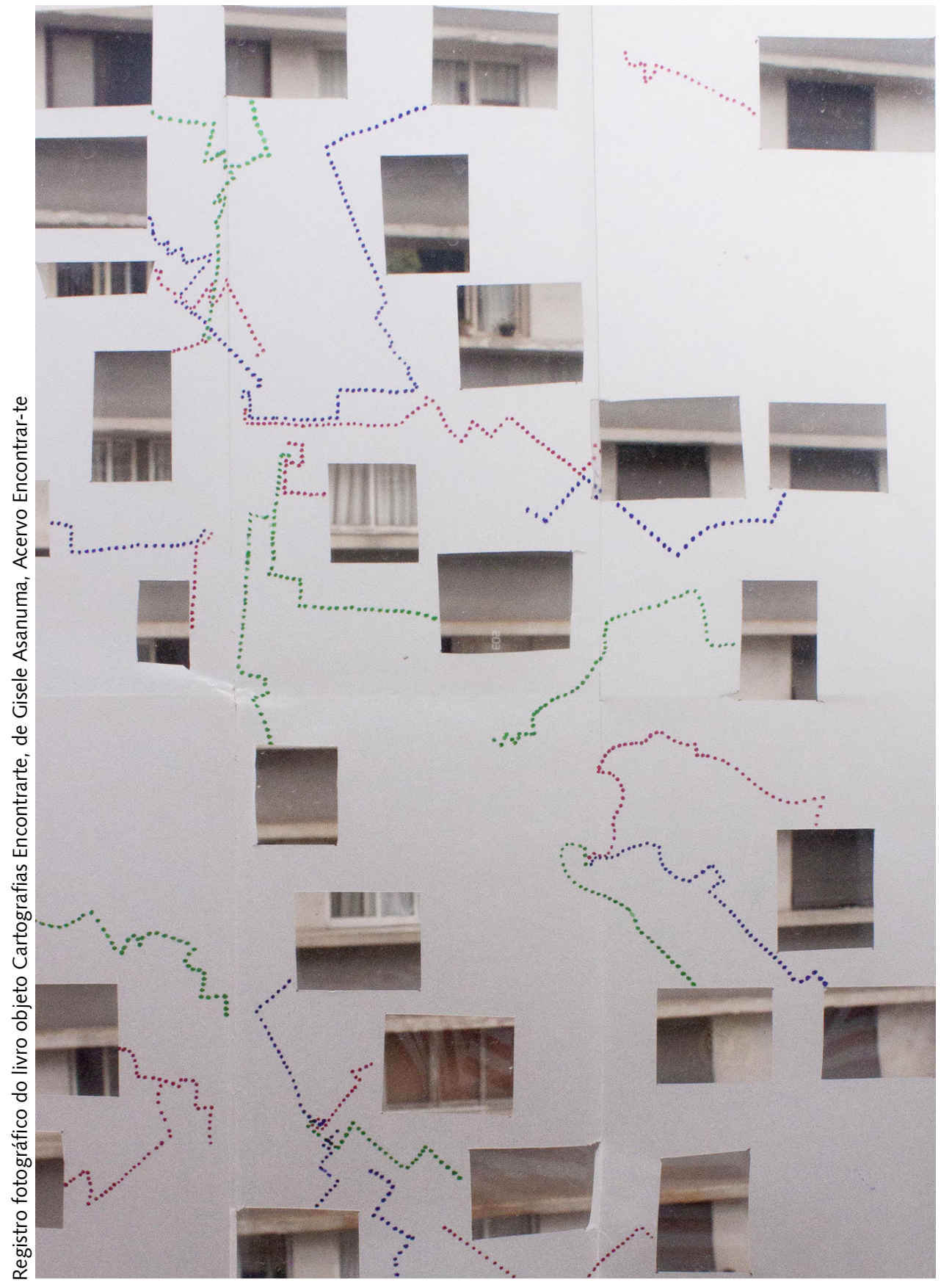




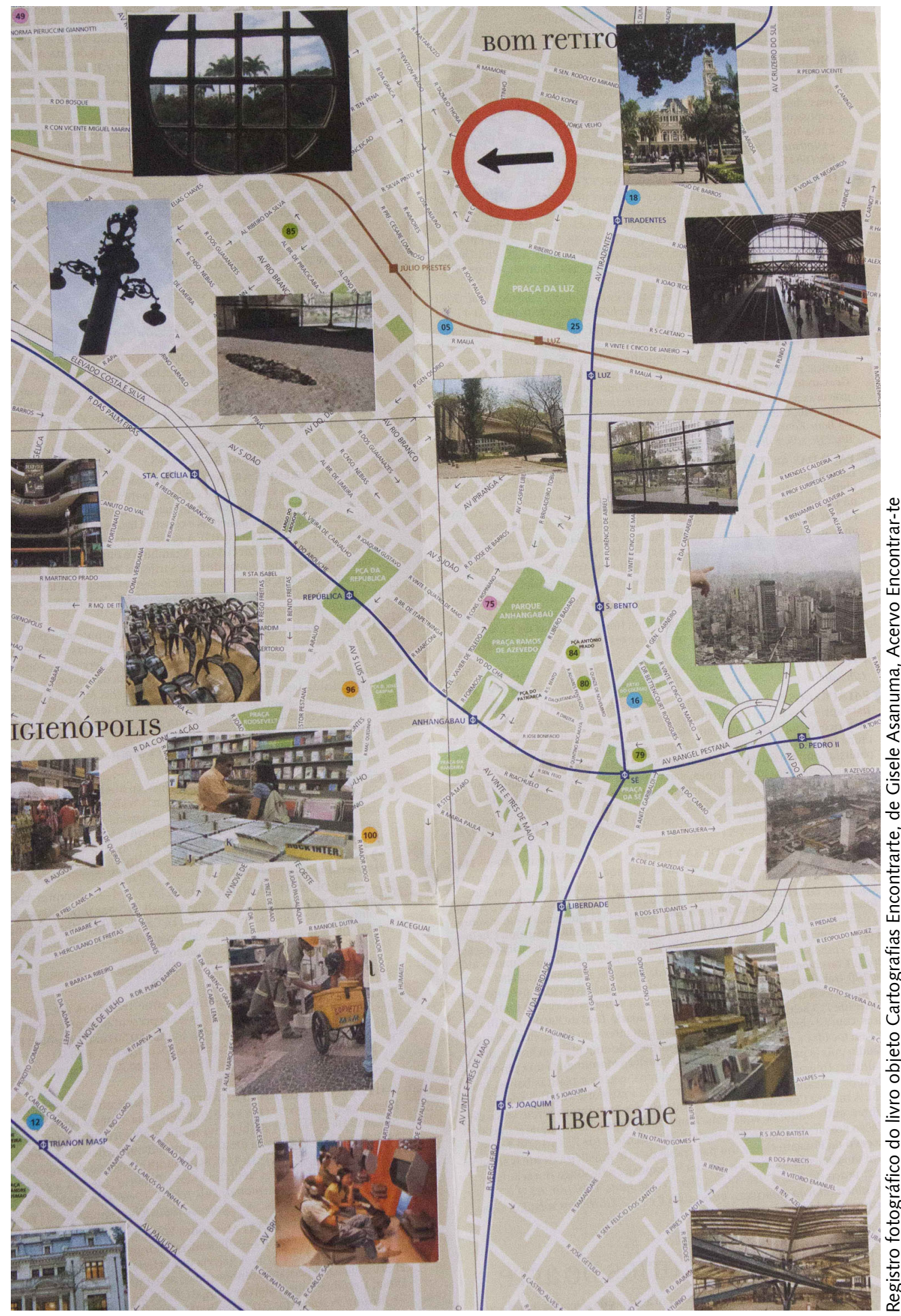

Abrir.

Abrir-se ao que juntos faríamos naquela tarde. Às imagens que os olhos podiam alcançar ou permitiam entrar. Disponibilidade para o outro, para o trânsito, para o acaso, para a cidade, para os transeuntes, para os sons...

Nada era preciso. Seguíamos.

E como anda um bando? Difícil saber quem lidera a caminhada. Quem decide quando ir? Como se dão esses acordos sem fala? 

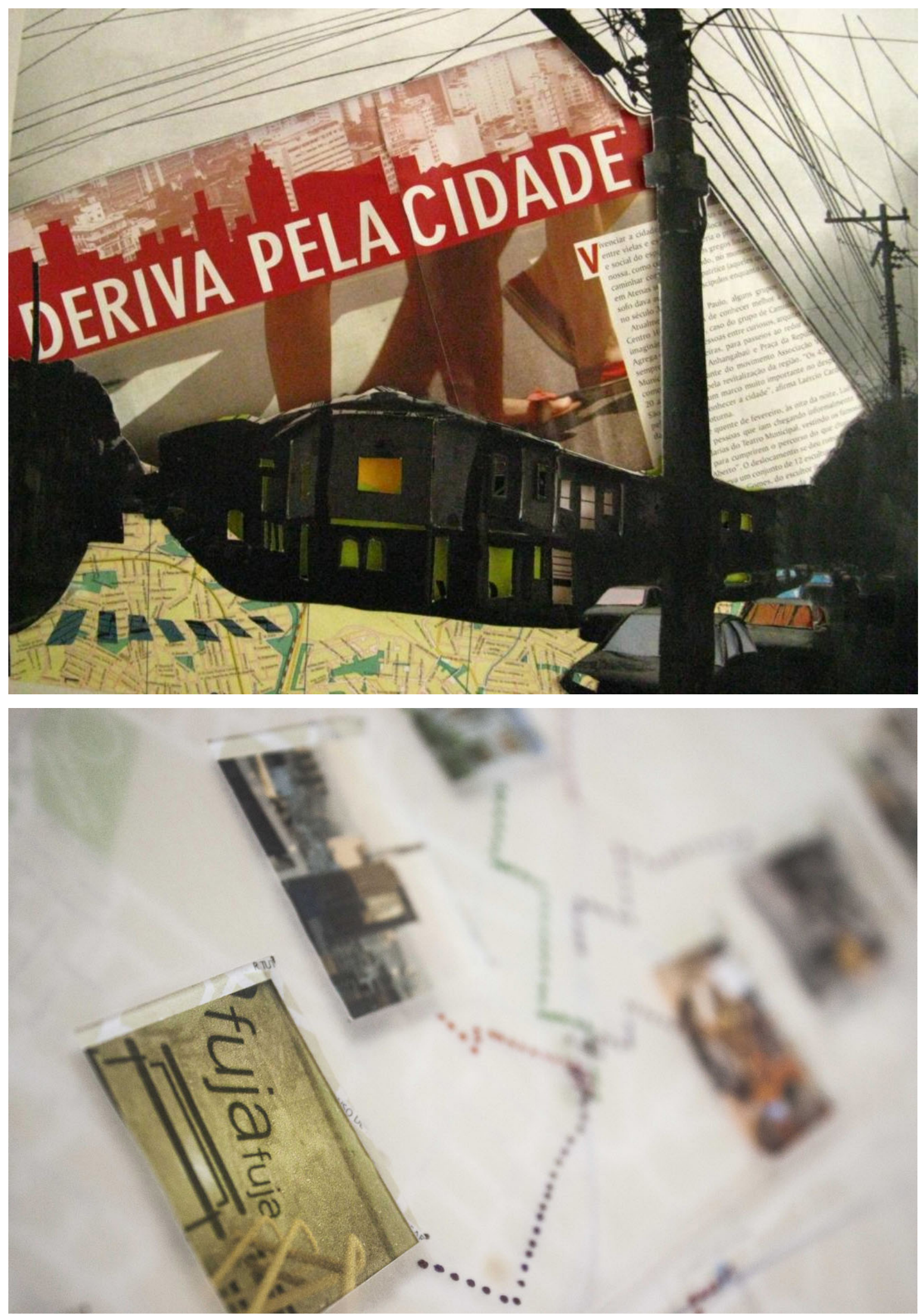

Registros fotográficos do livro objeto Cartografias Encontrarte, de Gisele Asanuma, Acervo Encontrar-te 
Passos apressados de um, talvez preocupado em traçar o caminho mais curto, mais reto ou mais breve e que, às vezes, se confundia com o único que conhecia.

Passos automáticos de outro, acompanhando o grupo de forma mimética. Parava, quando os outros paravam. Punha-se a caminhar quando os outros se movimentavam, em uma incrível capacidade de sincretizar seu movimento com os outros sem o recurso do olhar.

E havia aquele que caminhava pela guia das calçadas ou pela borda das ruas, mas nunca perto dos muros. Pelo meio da avenida 23 de maio, fora da faixa de pedestre, mas nunca em cima de uma ponte.

Um convite a ajustes constantes para encontrarmos uma distância que nos permita seguir juntos. Como seguir juntos sem a necessidade de impor um ritmo comum, uniforme? Não se trata de buscar nosso ritmo, como se precisássemos inventar uma unidade coletiva para podermos nos mover, mas de encontrar tacitamente um ritmo comum para que os ritmos de cada um possam pulsar em conexão.

Diferentes formas de circular no espaço. Cada um com sua organização sensorial, espacial e temporal, seus mapas prévios e outros elementos que povoam a experiência desse acontecimento coletivo. A noção de tempo se inverte e passa a ser vivida como a hesitação pela qual se engendra o que antes não havia, nem estava previsto ou era previsível, o tempo como criação contínua da imprevisível novidade.

Andar em bando permite experimentar outros modos de circular, deslocando os habituais, automáticos ou costumeiros. O corpo hesita, apressa ou retarda seu ritmo, em um esforço de nos mantermos próximos, de nos acompanharmos uns dos outros, exigindo novas orquestrações do tempo. 


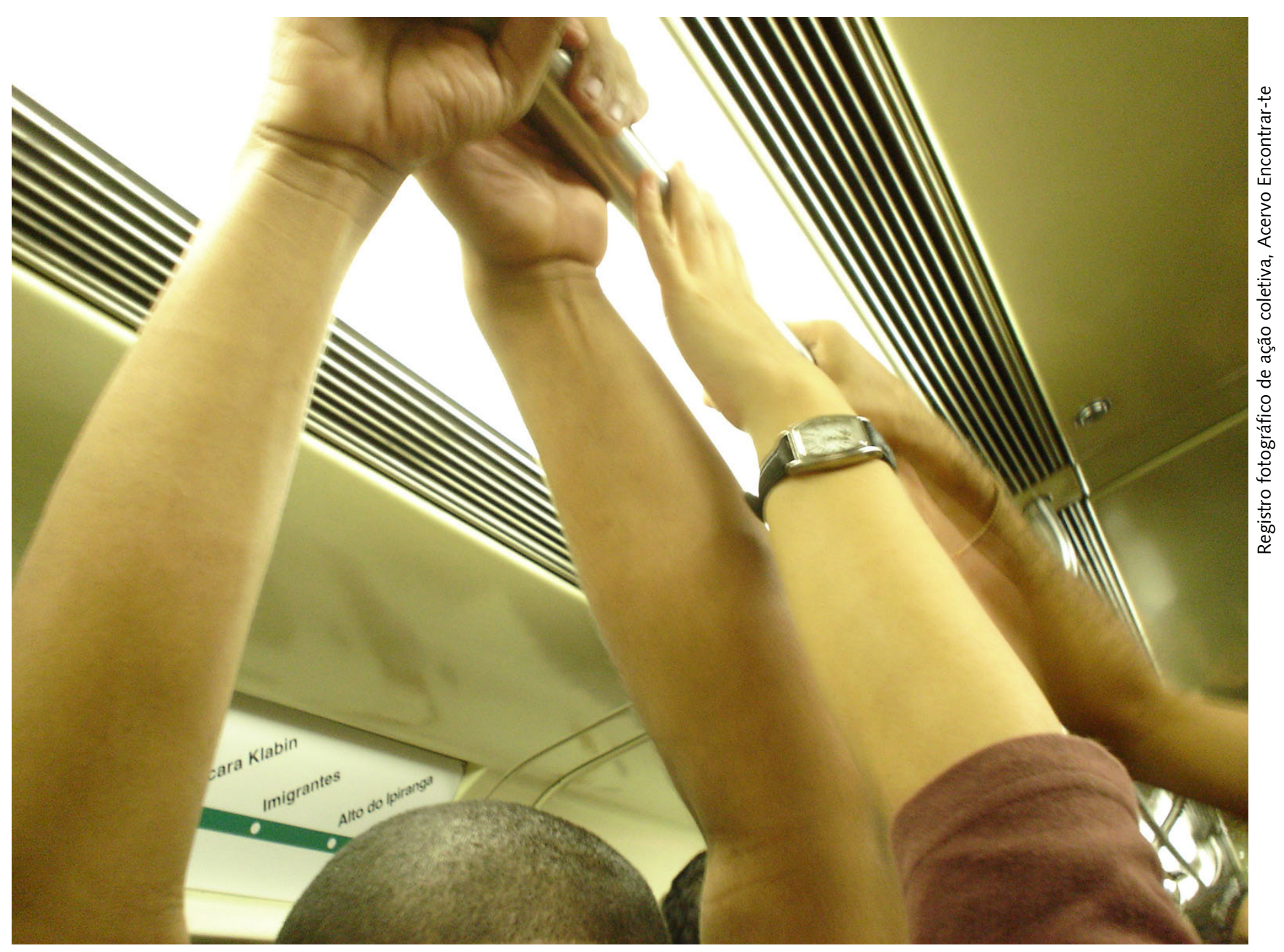

Saca-se da bolsa uma "trouxinha de dinheiro". Estava já o dinheiro exato, com moedas e notas. As moedas estavam "encapadas" pelas notas, formando uma "trouxinha". Então, vira-se com a " "trouxinha" para a moça do guichê: "Quero dois passes!". A moça, muito estranhada, desfez a trouxinha, hesitante, conferiu o valor a ser revelado pela "dobradura". Estava correto. Então, entregou-lhe dois passes. Mas ainda surpreenderia a moça do guichê: "Você pode destacar os bilhetes pra mim?". 
Outro do grupo, com a mesma atendente de guichê: "Um bilhete pra ida e outro pra volta". A moça rapidamente estica o braço e entrega o bilhete. Estava ainda transtornada com a abordagem anterior. A fila só aumentava. Desta vez, este usuário do metrô surpreenderia a moça com suas lentidões próprias. Ficou olhando, parado, como se a ação na compra do bilhete fosse apenas da atendente. A mulher então, muito irritada, bate com uma moeda no vidro e diz irritada, para apressá-lo:

"São R\$ 4,60". Ele resolve abrir a pochete e procurar o dinheiro. Muito lentamente, ele estica o braço com uma nota de $\mathrm{R} \$ 2,00$. "O dinheiro não dá!" Ele pega então, mais uma nota de R\$2,00. "Agora sim!" - diz ele, com a certeza e a alegria de conseguir concluir a operação com sucesso. O raciocínio parecia ser o seguinte, dois bilhetes, dois dinheiros. A moça do guichê a esta altura estava fuzilando-o com os olhos, a fila aumentava ainda mais. A tensão aumentava. Ele consegue então, dar mais uma nota de $\mathrm{R} \$ 1,00$. Recebe o troco e vamos embora, agora não mais fuzilados com o olhar da atendente da bilheteria, mas por toda fila que assistiu à cena que emperrou o fluxo da compra de bilhete de metrô. ${ }^{4}$ (p. 11-2)

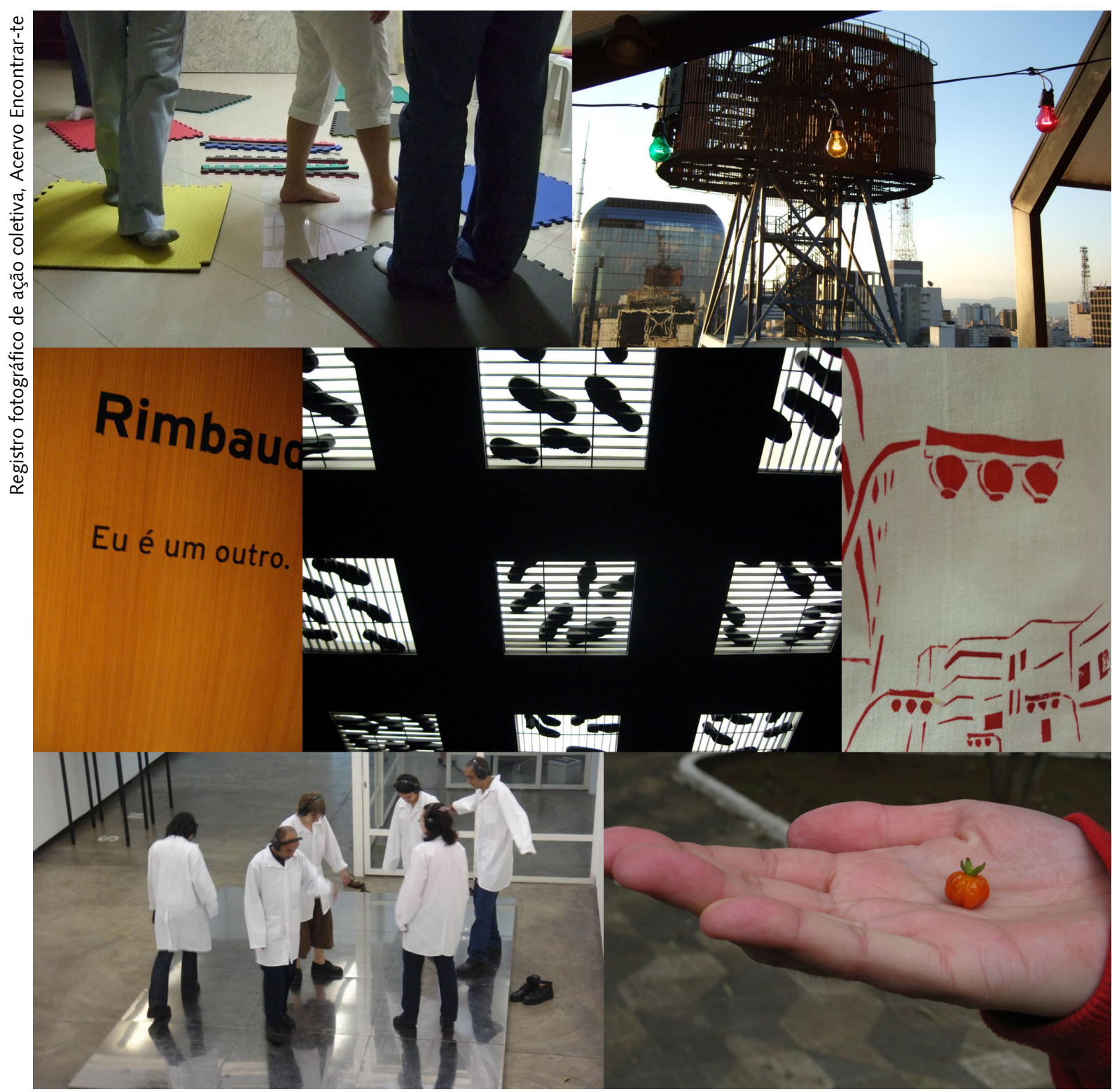


Uma embriaguez apodera-se daquele que, por um longo tempo, caminha a esmo pelas ruas. A cada passo, o andar adquire um poder crescente; as seduções das lojas, dos bistrôs e das mulheres sorridentes vão diminuindo, cada vez mais irresistível torna-se o magnetismo da próxima esquina, de uma longínqua massa de folhagem, de um nome de rua. $^{5}$ (р. 185)

Saber orientar-se numa cidade não significa muito. No entanto, perder-se numa cidade, como alguém se perde numa floresta, requer instrução. Nesse caso, o nome das ruas deve soar para aquele que se perde como o estalar do graveto seco ao ser pisado, e as vielas do centro da cidade devem refletir as horas do dia tão nitidamente quanto um desfiladeiro. ${ }^{6}$ (p. 73)

Andamos juntos, povoando, habitando, explorando, estranhando a cidade. Pegamos o metrô, atravancamos a bilheteria com as lentidões próprias, querendo pagar os dois bilhetes com os dois dinheiros. Irritamos as pessoas, desorientamos os atendentes, conversamos e desconversamos em várias línguas durante os trajetos. Os trajetos que percorremos, o ônibus que tomamos são todos eles espaços de incitação. Verdadeiros estrangeiros, seguimos viagem, desbravando a selva bruta, mata fechada de mau humor e sorrisos trancados. Mas nem ligamos, muitas vezes nem percebemos. A alegria da viagem, do encontro dissipa um tanto a presença dos que apertaram o botão do automatismo diário e estão indisponíveis para estar com outras pessoas.

A cada saída, uma orquestração de desconcertos - algum atendente de guichê, algum cobrador de ônibus, transeunte desatento, vendedor desavisado ou terapeutas neuróticos são convocados para um estranho encontro. Há uma incrível capacidade de tirar as pessoas dos eixos. O automatismo das funções, do funcionamento da cidade e de nós mesmas é colocado em xeque a cada encontro que o grupo trava com a cidade ${ }^{7}$.

Registro fotográfico do livro Cartografias Encontrate, de Gisele Asanuma, Acervo Encontrar-te

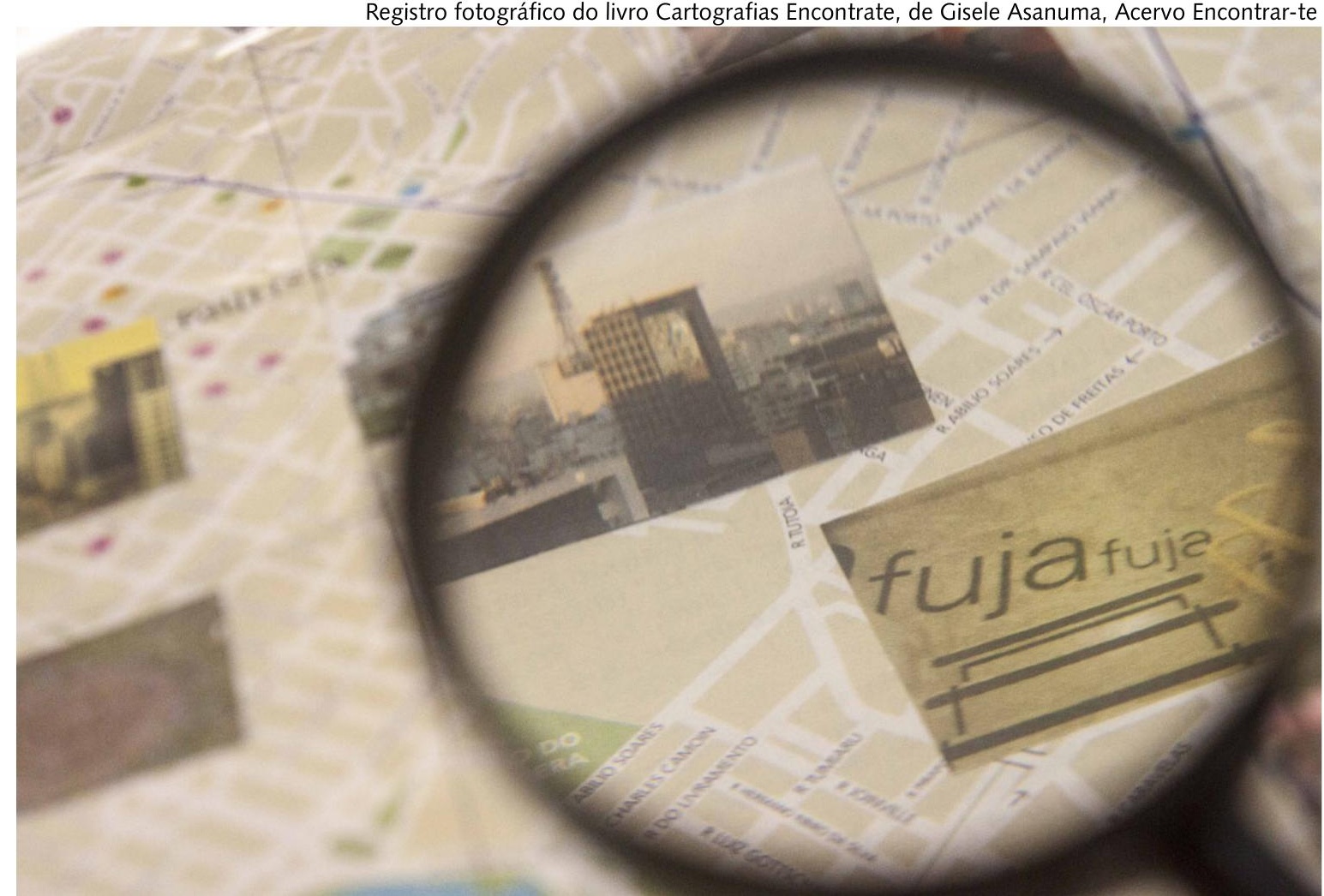




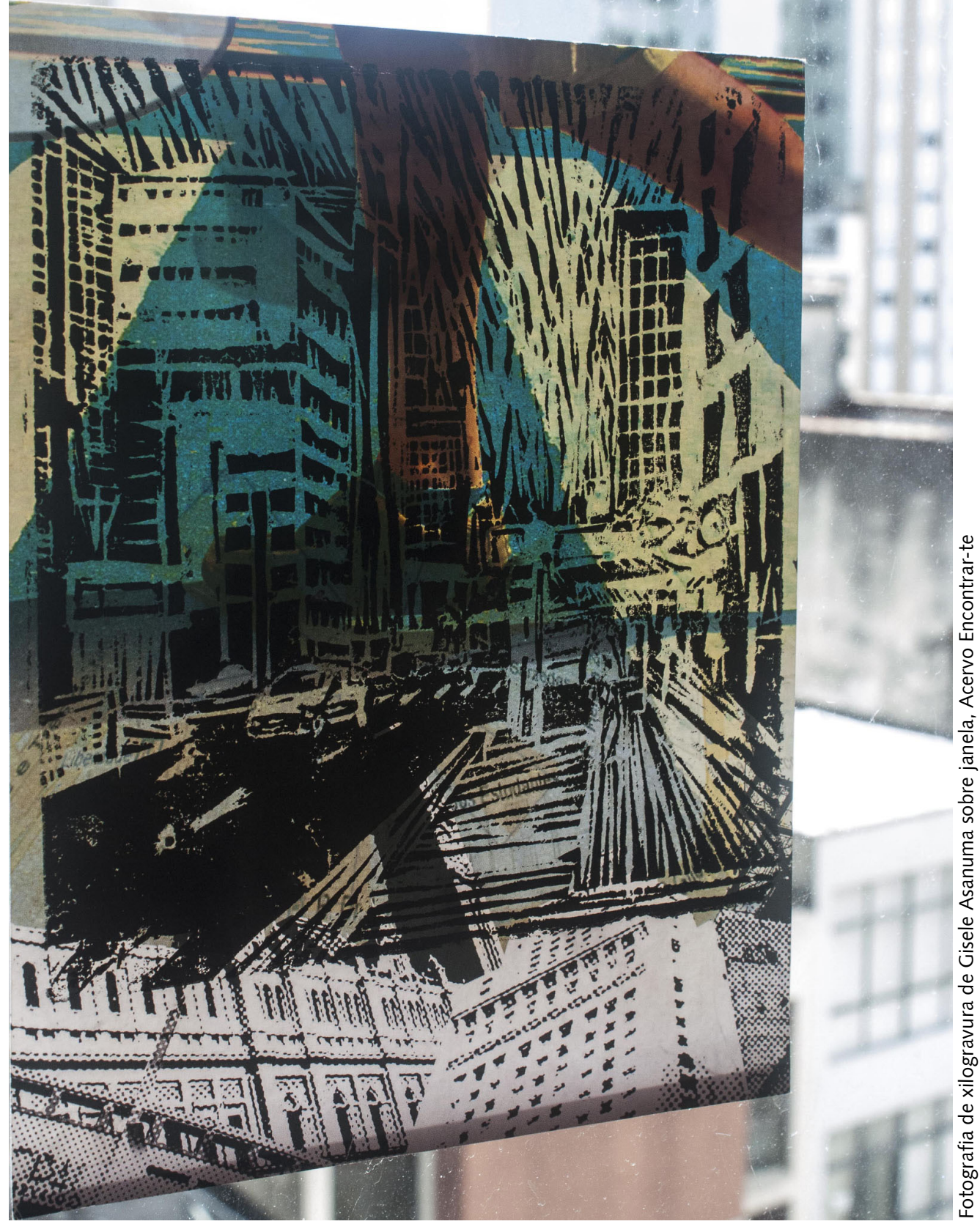

\section{Colaboradores}

Todas as autoras participaram ativamente da discussão dos resultados, da revisão e da aprovação da versão final do trabalho.

As imagens foram realizadas de forma colaborativa pelos participantes do Projeto Encontrar-te e compõem-se de montagens fotográficas a partir de registros, colagens e gravuras, editadas por Isabela Valent e Gisele Asanuma.

\section{Referências}

1. Deleuze G, Parnet C. Diálogos. São Paulo: Escuta; 1998.

2. Deleuze G. Crítica e clínica. São Paulo: Ed. 34; 1997.

3. Valent IU. Fazer imagens, inventar lugares: experimentações fotográficas e audiovisuais em práticas artísticas na interface arte, cultura e saúde [dissertação]. São Paulo (SP):

Universidade de São Paulo; 2014. 
4. Asanuma GD. Poéticas do inacabado: verbetes para uma clínica em trânsito [dissertação]. São Paulo (SP): Pontifícia Universidade Católica de São Paulo; 2010.

5. Benjamin W. Charles Baudelaire um lírico no auge do capitalismo. São Paulo: Brasiliense; 1989.

6. Benjamin W. Rua de mão única. São Paulo: Brasiliense; 1995.

7. Encontrar-te. Sutis acontecimentos no meio da multidão [curta-metragem audiovisual]. São Paulo: Distribuição independente; 2011 [citado 22 Fev 2018]. Disponível em: https:// vimeo.com/101228688.

Este trabalho apresenta imagens disparadas por modos de olhar e habitar a cidade de São Paulo, Brasil, desenvolvidos a partir da experiência do Projeto Encontrar-te entre os anos de 2005 e 2014. O projeto realizava saídas na cidade com um grupo formado a partir de uma composição heterogênea. A circulação por lugares da arte e da cultura em uma prática conectada com a invenção de formas de vida, de estar com o outro e de habitar a cidade compôs artifícios que favoreceram expressões poéticas, criativas e sensíveis; e a inauguração de gestos singulares.

Palavras-chave: Arte. Produção de subjetividade. Terapia ocupacional. Poética. Circulação urbana.

\section{Encontrar-te: poetic routes and invention of places}

This study presents images resulting from ways of looking at and living in the city of São Paulo, Brazil, based on the experiences of the Encontrar-te project between 2005 and 2014. Heterogeneous groups moved around the city as a routine activity in the project. The circulation in art and culture-related places in a practice connected to the invention of forms of living, being with other people and inhabiting the city originated skills that favored poetic, creative and sensitive expressions and the initiation of singular gestures.

Key words: Art. Subjectivity production. Occupational therapy. Poetry. Urban circulation.

\section{Encontrarte: trayectos poéticos e invención de lugares}

Este trabajo presenta imágenes disparadas por modos de mirar y habitar la ciudad de São Paulo, Brasil, desarrollados a partir de la experiencia del Proyecto Encontrarte entre los años 2005 y 2014. El proyecto realizaba recorridos por la ciudad con un grupo formado a partir de una composición heterogénea. La circulación por lugares del arte y de la cultura en una práctica conectada con la invención de formas de vida, de estar con el otro y de habitar la ciudad compuso artificios que favorecieron expresiones poéticas, creativas y sensibles y la inauguración de gestos singulares.

Palabras clave: Arte. Producción de subjetividad. Terapia ocupacional. Poética. Circulación urbana. 